$+b^{5}=0$, je dis que cette équation est la même chose que $\left(x^{5}+a x^{4}+b^{5}\right) / c^{2}=0$, ce qui réduit les dimensions à trois."'

"Remarquez qu'on peut toujours faire cette division; car, dans la géométrie, tout se réduit toujours à des équations. On ne considere (sic) $a^{4}$ que pour le comparer à quelque autre quantité de même dimension; et il est visible qu'une équation continue d'avoir lieu, lorsqu'on divise tous ses termes par une quantité constante quelconque. Ou bien on peut regarder $a$ et $b$ dans l'équation comme des nombres, qui soient entr'eux comme les lignes représentées par $a$ et $b$, et alors $x$ sera un nombre, et on n'aura que faire de division. Cette manière de considérer les quantités de plus de trois dimensions, est aussi exacte que l'autre; car les lettres algébriques peuvent toujours être regardées comme représentant des nombres, rationels ou non. J'ai dit plus haut qu'il n'étoit pas possible de concevoir plus de trois dimensions. Un homme d'esprit de ma connaissance croit qu'on pourroit cependant regarder la durée comme une quatrieme (sic) dimension, et que le produit du tems $(s i c)$ par la solidité, serait en quelque maniere (sic) un produit de quatre dimensions; cette idée peut être contestée, mais elle a, ce me semble, quelque mérite, quand ce ne servoit que celui de la nouveauté."

BRown UNIVERSITY,

Providence, R.I.

December 26, 1913.

\title{
THE DISCOVERY OF INVERSION.
}

Über Bizentrische Polygone, Steinersche Kreis-und Kugelreihen und die Erfindung der Inversion. By F. BüTZBERGER. B. G. Teubner, Leipzig, 1913 . viii $+60 \mathrm{pp}$.

As indicated by the title, this interesting monograph consists of three chapters in which Professor Bützberger presents the results of a critical and historical investigation on bicentric polygons, Steinerian series of circles and spheres, and the discovery of inversion.

The first chapter treats of polygons which are simultaneously inscribed to one and circumscribed to the other of two nonintersecting circles in a plane. The conditions for closure of such polygons have been investigated by Poncelet, and it is for this reason that they are frequently called Poncelet's 
polygons. Jacobi, as is well known, gave an elegant solution of Poncelet's problem by means of elliptic functions and this is still the best method not only for this but also for a great number of other problems of closure. Bützberger's method is very direct and elementary and aims to follow the trail which presumably led Steiner to the equations between the radii and the distance $e$ between the centers of two circles with the property of closure, of which one with radius $r$ encloses the other with radius $\rho$. In case of such enclosure the corresponding rectilinear polygons are called bicentric. When $e=1$ and $r=2$, the equations have the remarkable property that the sum of their coefficients is always unity. The equation for a polygon of eight sides, for example, is

$$
8704 \rho^{8}-23040 \rho^{6}+36936 \rho^{4}-29160 \rho^{2}+6561=0,
$$

and the sum of the coefficients is

$$
52201-52200=1 .
$$

In the second chapter we find a discussion of Steiner's series of circles and spheres. Most of the problems connected with these series have been studied by a number of geometers and by various methods, and there is practically no new ground covered in this part of the book.

It seems that the author is not familiar with some recently established properties of closure in connection with linkages. For example, all problems concerning Poncelet's polygons (making use of inversion) and Steinerian series result as special cases from the theorem:

If each pair of consecutive circles of a series of circles which all touch two circles $C_{1}$ and $C_{2}$, of which $C_{2}$ encloses $C_{1}$, intersect in two points $B_{i}$ and $B_{i}{ }^{\prime}$ and if the points $B_{1}, B_{2}, B_{3}, \cdots$ are on a circle $C_{3}$, then the points $B_{1}{ }^{\prime}, B_{2}{ }^{\prime}, B_{3}{ }^{\prime}, \ldots$ are also on a circle $C_{4}$. If the series of circles closes and contains $n$ circles, then every other series based upon the same circles $C_{1}, C_{2}, C_{3}$ closes and contains $n$ circles.*

* This theorem was found by the writer in 1901. See "An application of elliptic functions to certain linkages," in Annals of Mathematics, 2d series, vol. 2; also "Applications of elliptic functions to problems of closure," University of Colorado Studies, vol. 1, pp. 81-133 (1902); and "Kinematische Gelenksysteme und die durch sie erzeugten geometrischen Transformationen," Jahresbericht der Kantonsschule, Solothurn (1907).

In an article "On circular transformations," Annals of Mathematics, vol. 12, pp. 141-160 (1899), most of the ordinary problems in Steinerian series are proved in a simple manner. 
The third chapter, in which an account of the discovery of inversion (transformation by reciprocal radii) is given, is in our judgment the most important.

After the death of Steiner in 1863, his unpublished manuscripts, letters, and scientific fragments were deposited in the city library of Bern, where 30 years later Professor Graf rescued them from oblivion. He turned them over to Professor Bützberger for critical study and eventual publication.

As early as 1826 Steiner had nearly finished a manuscript of 360 pages, ready for print, on "Allgemeine Theorie des Berührens und Schneidens der Kreise in der Ebene, der Kugeln im Raum, und der Kreise auf der Kugelfläche, mit vielen neuen Sätzen und Untersuchungen in einem systematischen Entwicklungsgange dargestellt."

According to Bützberger, after the publication of this work and Steiner's explicit statement of the principle of inversion, dated February 8, 1824, and published on pages 50-55 of the work under review, there cannot be the slightest doubt that it was Steiner who first established and applied what Liouville in 1847 called the transformation by reciprocal radii. From the nature of a great number of remarkable theorems published by Steiner in the early volumes of Crelle's Journal it had long been suspected that Steiner was familiar with this transformation and made extended use of it. Plücker's insinuation in an article published in the same journal, where he gave an analytic proof of Steiner's famous solution of Malfatti's problem and its generalization, that Steiner had probably no proof for his construction, was manifestly unfair. It simply shows that Plücker had no conception and consequently no appreciation of the great power and originality of Steiner's methods. Steiner on the other hand disdained as "caricatures" some trivial applications which Plücker and also Magnus made of the principle of inversion.

In the following decades the same transformation was found independently by several investigators: By Bellavitis* in 1836, by J. W. Stubbs† and J. R. Ingram $\ddagger$ in 1842 and 1843 and by William Thomson§ (Lord Kelvin) in 1845.

* Annali delle Scienze, Padova, vol. 17, p. 126.

$\dagger$ Philosophical Magazine, vol. 23, pp. 338-347. The title of the paper referred to is "On the application of a new method to the geometry of curves and curve surfaces." January $31,1843$.

\$Transactions of the Dublin Philosophical Society, vol. 1, 1842-43.

\$Journal de Mathématiques pures et appliquées, vol. 10, pp. 364-367, "Extrait d'une lettre de M. William Thomson"; vol. 12, pp. 256-290, "Extrait de deux lettres addressées à M. Liouville," 1846. 
The little book is carefully and clearly written and contains only a few minor errors. On page 58, second line from bottom, read "Nouvelle méthode" instead of "Nouvelles Méthodes." On the next page read J. W. instead of J. J. Stubbs. The reference to J. W. Stubbs and J. R. Ingram is ambiguous. In the Philosophical Magazine Stubbs does not make the least reference to Ingram, and evidently claims priority of the discovery.

ARNold EMch.

\section{SHORTER NOTICES.}

Poliedri, Curve e Superficie secondo $i$ Metodi della Geometria descrittiva. By Gino LoRIA, professor of mathematics at the University of Genoa. Milan, Ulrico Hoepli, 1912. (Manuali Hoepli, nos. 148-149.) $\quad x v+235$ pages and 62 figures.

Vorlesungen über darstellende Geometrie. Zweiter Teil: Anwendungen auf ebenflächige Gebilde, Kurven und Flächen. By Gino Loria. Autorisierte, nach dem italienischen Manuskript bearbeitete, deutsche Ausgabe, by Fr. ScHüTTE, teacher in the gymnasium at Düren. (Teubner's Sammlung, no. $\mathrm{XXV}_{2}$.) Leipzig and Berlin, B. G. Teubner, 1913. xii +294 pages and 146 figures.

THE present volume of Professor Loria's treatise presupposes a knowledge of the previous one (Metodi di Geometria descrittiva). It is concerned with the applications of the principles there developed to the graphical representation of polyhedra, curves, and surfaces. The style is clear and concise, and each step of a procedure is fully explained, but the theorems of analytical geometry and of the calculus that are made use of are stated without proof or reference, thus providing a series of statements having very questionable value. If the reader is already familiar with these theorems, they need not be repeated here; if he is not familiar with them, the words will convey little, if any, meaning to him.

The first chapter is concerned with the graphical solution of spherical triangles, incidentally including the derivation of the fundamental formulas of spherical trigonometry. The next two chapters discuss the representatiod of prisms, pyramids, and polyhedra, together with theis development and 